\begin{tabular}{|l|l|l||}
\hline \multicolumn{2}{|c|}{ PublisherInfo } \\
\hline \hline PublisherName & $:$ & BioMed Central \\
\hline \hline PublisherLocation & $:$ & London \\
\hline \hline PublisherImprintName & $:$ & BioMed Central \\
\hline \hline
\end{tabular}

\title{
Integrating genomics and proteomics
}

\begin{tabular}{|l|l|l||}
\hline \multicolumn{2}{|c|}{ ArticleInfo } \\
\hline \hline ArticleID & $:$ & 4078 \\
\hline \hline ArticleDOI & $:$ & $10.1186 /$ gb-spotlight-20010508-01 \\
\hline \hline ArticleCitationID & $:$ & spotlight-20010508-01 \\
\hline \hline ArticleSequenceNumber & $:$ & 149 \\
\hline \hline ArticleCategory & $:$ & Research news \\
\hline \hline ArticleFirstPage & $:$ & 1 \\
\hline \hline ArticleLastPage & $:$ & 2 \\
\hline \hline & & RegistrationDate : 2001-05-08 \\
ArticleHistory & $:$ & OnlineDate $\quad$ 2001-05-08 \\
\hline \hline ArticleCopyright & $:$ & BioMed Central Ltd2001 \\
\hline \hline ArticleGrants & $:$ & \\
\hline \hline ArticleContext & $:$ & 130592211 \\
\hline \hline
\end{tabular}




\section{Jonathan B Weitzman}

Email: jonathanweitzman@hotmail.com

Large-scale methods for gene profiling or protein quantification are the focus of genomic and proteomic studies. But new approaches are needed to integrate these data sets and create biological models that can predict cellular behaviour. In the May 4 Science, Ideker and colleagues, at the Institute for Systems Biology in Seattle, describe an integrated approach to create a model of cellular metabolic pathways (Science 2001, 292:929-934). Their approach is based on four steps: defining all the genes/ proteins in a given pathway, perturbing each component and detecting changes, integrating RNA/protein changes into a pathway model, and formulating hypotheses and predictions. As a proof-of-principle they investigated the galactose-utilization (GAL) pathway in yeast, in which most of the genes and protein interactions have already been identified. They tested a number of gal mutant strains under different environmental growth conditions and examined global changes in mRNA expression using microarrays and in protein levels using tandem mass spectrometry. They identified 997 changes in mRNAs levels and 15 proteins that were post-transcriptionally regulated. This analysis also identified interactions that govern the GAL network and suggested novel hypotheses that could be experimentally verified.

\section{References}

1. Exploring the new world of the genome with DNA microarrays.

2. Quantitative analysis of complex protein mixtures using isotope-coded affinity tags.

3. Science, [http://www.sciencemag.org]

4. Institute for Systems Biology, [http://www.systemsbiology.org]

5. Transcriptional regulation in the yeast GAL gene family: a complex genetic network. 